\title{
The polar expression of ENSO and sea-ice variability as recorded in a South Pole ice core
}

\author{
Eric A. Meyerson, ${ }^{1}$ Paul A. MAYEWSKi, ${ }^{1}$ Karl J. KReUtZ, ${ }^{1}$ L. David MEEKER, ${ }^{2,3}$ \\ Sallie I. WHITLOW, ${ }^{2}$ Mark S. TWICKLER ${ }^{2}$ \\ ${ }^{1}$ Institute for Quaternary and Climate Studies and Department of Geological Sciences, University of Maine, Orono, ME 04469-57902, U.S.A. \\ E-mail: eric.meyerson@maine.edu \\ ${ }^{2}$ Climate Change Research Center, Institute for the Study of Earth, Oceans and Space, University of New Hampshire, Durham, NH 03824, U.S.A. \\ ${ }^{3}$ Department of Mathematics, University of New Hampshire, Durham, NH 03824, U.S.A.
}

\begin{abstract}
An annually dated ice core recovered from South Pole (2850 m a.s.l.) in 1995, that covers the period 1487-1992, was analyzed for the marine biogenic sulfur species methanesulfonate (MS). Empirical orthogonal function analysis is used to calibrate the high-resolution MS series with associated environmental series for the period of overlap (1973-92). Utilizing this calibration we present a $\sim 500$ year long proxy record of the polar expression of the El Niño-Southern Oscillation (ENSO) and southeastern Pacific sea-ice extent variations. These records reveal short-term periods of increased (1800-50, 1900-40) and decreased sea-ice extent (1550-1610, 1660-1710, 1760-1800). In general, increased (decreased) sea-ice extent is associated with a higher (lower) frequency of El Niño events.
\end{abstract}

\section{INTRODUGTION}

The El Niño-Southern Oscillation (ENSO) phenomenon is the largest known single source of global interannual climatic variability (Diaz and Markgraf, 1992), as illustrated by the worldwide climate anomalies that are associated with the atmospheric and oceanic fluctuations in the ENSO center of action, the tropical Indian-Pacific Ocean (Glantz, 1991; Diaz and Kiladis, 1992). The majority of studies have understandably focused on the ENSO center of action in the tropical Pacific and climate teleconnections in the low to mid-latitudes.

Instrumental linkages between the high southern latitudes and the tropics demonstrate the existence of an AntarcticENSO climate connection in several different ways: annual temperatures at South Pole are positively correlated to annual values of the Southern Oscillation Index (SOI) of the previous year (Savage and others, 1988; Smith and Stearns, 1993); an eastward shift in Amundsen Sea low (ASL) pressure is noted during El Niño events from 1980 to 1990 (Cullather and others, 1996; Bromwich and others, 2000); analysis of satellite-derived Antarctic sea-ice extent data reveals El Niño-associated periodicities (Gloersen, 1995); key sea-ice regions in the Pacific sector are positively related to the SOI (Carleton, 1989; Simmonds and Jacka, 1995); and sea-ice concentrations are reduced in the Ross Sea region during El Niño events (Ledley and Huang, 1997).

Most attempts at developing a reliable paleoclimate proxy for ENSO have focused on the tropics and subtropics (Stahle and others, 1998). Notably, historical records originating from the west coast of South America provide a reliable proxy of El Niño events well beyond the instrumental record (Quinn, 1992; Quinn and Neal, 1992), significantly increasing the temporal coverage of ENSO variations. In addition, an ice core covering the time period $1922-84$ from South Pole and examined by Legrand and Feniet-Saigne
(1991) yielded evidence that sub-annually resolved methanesulfonate (MS) and non-sea-salt sulfate $\left(\mathrm{SO}_{4}{ }^{2-}\right)$, both of which are produced from the photo-oxidation of the marine biogenic species dimethylsulfide (Charlson and others, 1987; Saigne and Legrand, 1987), clearly show perturbations that are associated with El Niño events in the historical record (Quinn and others, 1987).

Ice-core measurements of MS have also been used to determine past fluctuations in Antarctic sea ice at coastal sites (Welch and others, 1993; Phillips, 1998). These studies reveal a positive relationship between increased MS and increased sea-ice extent in the adjacent ocean sector, most likely because of the increased productivity due to the growth of phytoplankton in and under the ice, as well as at the ice edges (Bunt and Wood, 1963; Clarke and Ackley, 1984; Nelson and others, 1987; Welch and others, 1993). Studies of Antarctic sea-ice extent are of great importance not only because of their potential link to ENSO, but also because Antarctic sea-ice variations have been shown to have a major influence on Southern Hemisphere atmospheric circulation patterns (Carleton, 1989) such as the Antarctic circumpolar wave (White and Peterson, 1996).

\section{METHODS}

A $71 \mathrm{~m}$, high-resolution ice core, covering the period 14871992, was collected at South Pole (snow accumulation rate $\sim 8.0 \pm 2.0 \mathrm{~cm} \mathrm{a}^{-1}$ w.e.) at a site $\sim 1.5 \mathrm{~km}$ upwind in the designated clean-air sector in 1995 (henceforth SP95). SP95 was shipped frozen to the Climate Change Research Center, University of New Hampshire, U.S.A., for processing and analysis. Ultra-clean procedures (Buck and others, 1992) were used to section the core at $\sim 2 \mathrm{~cm}$ intervals to obtain subannual resolution (8.2 samples per year, 1900-92; 6.5 samples per year, 1700-1899; 5.7 samples per year, 1487-1699). The core 


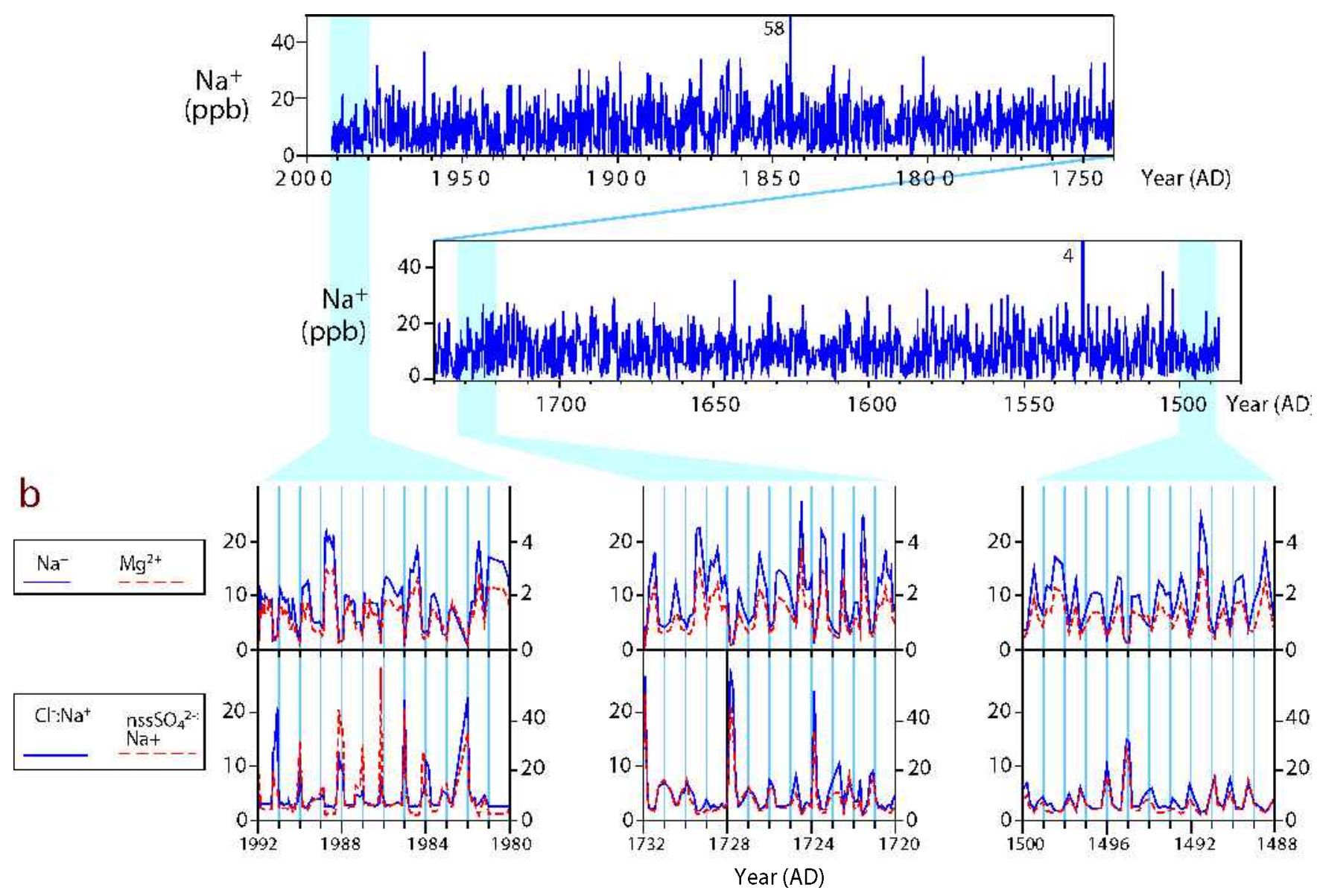

Fig. 1. Annual chemistry layers in the 1995 South Pole ice core used for dating. (a) Sub-annually resolved ice-core $\mathrm{Na}^{+}$( ppb) for 14871992. (b) Detailed 12 year sections (1488-1500, 1720-32, 1980-92) displaying winter-maxima chemical species on top ( $\mathrm{Na}^{+}$, solid line; $\mathrm{Mg}^{2+}$, dashed line) and summer-maxima chemical species on bottom ( $\mathrm{Cl} / \mathrm{Na}$, solid line; $\mathrm{nssO}_{4}{ }^{2-} / \mathrm{Na}^{+}$, dashed line).

was sub-annually dated using seasonal maxima in several chemical species $\left(\mathrm{SO}_{4}{ }^{2-}, \mathrm{Cl}^{-}, \mathrm{Na}^{+}, \mathrm{Mg}^{2+}\right.$ ) (Fig. 1) (Meyerson, 1999) in order to focus on the MS record. Cation $\left(\mathrm{Na}^{+}, \mathrm{Mg}^{2+}\right)$ concentrations were determined using Dionex ${ }^{(i \times}$ ion chromatography with a Dionex CS12 column, 20 mM methanesulfonic acid eluent and a $0.50 \mathrm{~mL}$ sample loop. Anion $\left(\mathrm{Cl}^{-}\right.$, $\mathrm{SO}_{4}{ }^{2-}$ ) concentrations were determined using a Dionex ${ }^{(i \times}$ ASll column, $6.0 \mathrm{mM} \mathrm{NaOH}$ eluent and a $0.25 \mathrm{~mL}$ sample loop. MS concentrations were obtained with a Dionex ${ }^{(i x}$ AS11 column with $0.1 \mathrm{mM} \mathrm{NaOH}$ eluent and a $1.50 \mathrm{~mL}$ sample loop. The resultant annually dated MS time series is used to develop a sea-ice proxy series and to extend the previous 1922-84 South Pole MS-El Niño relationship (Legrand and Feniet-Saigne, 1991) over the time period 1487-1992.

The 1487-1992 SP95 MS record is characterized by highfrequency interannual variations superimposed on longer (decadal and lower) frequency patterns (Fig. 2). It is also characterized by increasing values from the mid-20th century to the present, and limited migration from summer to winter layers below $\sim 3.5 \mathrm{~m}$ (AD 1980). The decreasing trend in SP95 MS from surface concentrations of $25 \mathrm{ppb}$ to an average background concentration level of $5 \mathrm{ppb}$ at $10.5 \mathrm{~m}$ depth (AD 1940) (Fig. 2) is similar to the MS decrease in the Vostok (Antarctica) ice core (snow accumulation rate $\sim 2.2 \mathrm{~g} \mathrm{~cm}^{-2}$ $\mathrm{a}^{-1}$ ) (Fig. 3) from $20 \mathrm{ppb}$ to a baseline of $2 \mathrm{ppb}$ at $\sim 5.5 \mathrm{~m}$ depth that is attributed to post-depositional modification (Wagnon and others, 1999). Thus we assume that there is some postdepositional loss of MS in the upper $10.5 \mathrm{~m}$ (AD 1940) of the
SP95 core, but believe it is limited to the uppermost portion of the SP95 MS record, as illustrated by the increased mean and variance from 1940 to 1992 (10.42, 23.79, respectively) relative to $1487-1940$ (4.99, 4.79, respectively). A $t$ test of mean MS concentrations for 1940-92 and 1487-1939 demonstrates that the distribution of MS values from 1487 to 1940 is significantly different from 1940-92, and leads us to conclude that further post-depositional loss of MS does not affect SP95 MS concentrations below $10.5 \mathrm{~m}$ depth ( $\sim$ AD 1940). Migration of MS has also been noted in the Siple Dome ice core (Kreutz and others, 1998) and other Antarctic coastal sites (Mulvaney and others, 1992), but limited movement of summer-deposited MS into adjacent winter layers at this site has been demonstrated not to affect the investigation of climate signals at the annual scale and higher (Kreutz and others, 1998; Legrand and Pasteur, 1998).

Other prominent features in the MS record are steps in the baseline concentration at $\sim 1575, \sim 1620$ and $\sim 1940$ (Fig. 2). The $\sim 1940$ step is synchronous with the prolonged El Niño conditions from July 1939 to June 1942 (negative values in the SOI) recorded as three relatively strong El Niño events in the historical record (1939, 1940-41, 1943) (Quinn and Neal, 1992). This step is also observed in other records: Tarawa (Kiribati) coral $\delta^{18} \mathrm{O}$ proxy series for the SOI (Cole and others, 1993); annually resolved Southern Hemisphere temperature series (Hansen and Lebedeff, 1988); and South Pole ice-core deuterium (Jouzel and others, 1983). Collectively, these records indicate a regional shift in the climate 
a
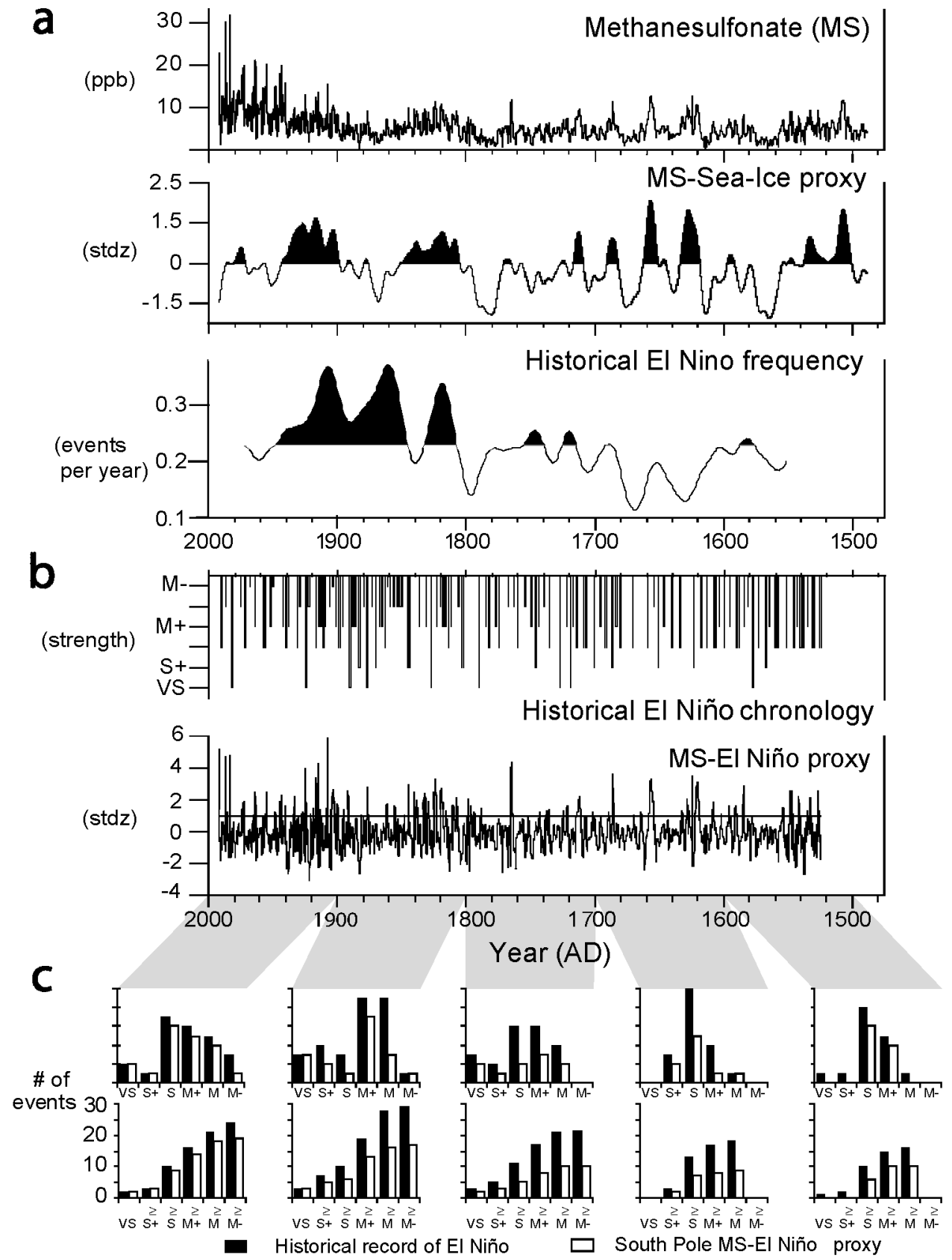

Fig. 2. The 500 year South Pole ice-core MS time series and the MS-sea-ice and MS-El Niño proxy records. (a) The sub-annually resolved MS (ppb) time series is shown with the calibrated MS-sea-ice proxy for sea-ice extent. Also shown is the frequency (51 year Gaussian filter) of El Niño events developed from the historical chronology (Anderson, 1992; Quinn and Neal, 1992). (b) The historical chronology of El Niño events (Quinn and Neal, 1992) with strength ratings (increase downward: moderate (M), strong $(S)$ and very strong (VS) is shown opposite the South Pole MS-El Niño proxy record developed from the MS residuals. El Niño events in the MS proxy $\geq 1 \sigma$ (horizontal line). (c) Comparison results between the MS-El Niño proxy and the historical El Niño chronology by century for individual strength events (top) and for cumulative strength events (bottom).

system at $\sim 1940$. Other large steps in MS at $\sim 1575$ and $\sim 1620$ were also accompanied by strong El Niño events (1574, 1618-19) (Quinn and Neal, 1992).

Exploratory empirical orthogonal function (EOF) decomposition analysis was conducted on the SP95 MS record, Amundsen-Ross (AR) sea-ice extent anomalies $\left(185-245^{\circ} \mathrm{E}\right)$, the SOI, and South Pole surface pressure and temperature anomalies for the period 1973-92 in order to statistically identify associated variances in the AntarcticENSO-sea-ice system. The SP95 MS series was first resampled to 12 samples per year for correlation with the monthly SOI, sea-ice and South Pole meteorological series. This allows the MS series to be matched with the monthly instrumental series for the EOF decomposition. The resampling of high-resolution proxy data to match monthly instrumental series (e.g. SOI, meteorological series) is demonstrated by Cole and others (1993) in their discussion of the Tarawa coral record. Sea-ice-extent monthly anomaly time series developed from monthly latitudinal sea-ice extent records compiled by Jacka (1983; with updates) for every $10^{\circ}$ of longitude from U.S. Navy and U.S. National Oceanic and Atmospheric Administration (NOAA) Joint Ice Center satellite-derived maps. Monthly SOI values, obtained from the Australian Bureau of Meteorology, were calculated using the Troup definition of the SOI (standardized anomaly of Tahiti minus Darwin mean monthly sea-level pressure). South Pole Station 


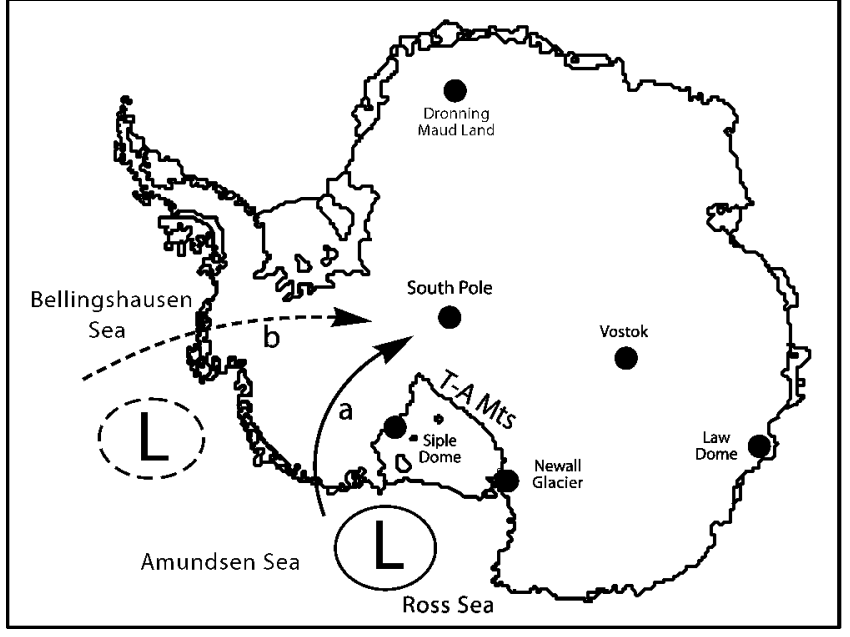

Fig. 3. Location map and schematic of MS transport to South Pole. The general location of the Amundsen Sea low-pressure system ( $L$ denotes the center of low) is from Cullather and others (1996) for typical pressure patterns for (a) normal (solid circle and arrow), and (b) reduced (dotted circle and arrow) West Antarctic (180-240 ) precipitation events (1980-90). Arrows generalize the transport pathways for MS: transport pathway a represents sea-ice-associated MS transport to South Pole from Amundsen-Ross (AR) sea-ice sector; transport pathway b represents El Niño-MS transport not related to AR sector that travels upslope to South Pole. The Transantarctic ( T-A) Mountains are also shown.

(SPS) surface pressure time series were obtained from Jacka and others (1984) (1957-77) and from the Climate Monitoring and Diagnostics Laboratory of the NOAA (1977-92). SPS surface temperature monthly time series were obtained from Jacka and others (1984; with updates).

The rationale behind investigating the $\mathrm{AR}$ sea-ice sector $\left(185-245^{\circ} \mathrm{E}\right)$ is based on previous work in this region. First, this sector has been identified as an air-mass source region for theWest Antarctic ice sheet, of which South Pole is situated on the southern flank (Cullather and others, 1996; Hogan, 1997; Bromwich and others, 2000). Additionally, there are multiple studies documenting the instrumental relationships between sea ice and ENSO in the AR region/southeastern Pacific (Carleton, 1989; Simmonds and Jacka, 1995; Ledley and Huang, 1997). The AR sector is also the adjacent region to South Pole in terms of distance, and this has been shown to be important for MS ice-core series (Welch and others, 1993; Phillips, 1998). The time period of study was constrained by sea-ice extent (satellite measurements started in 1973) and the SP95 core (most recent year 1992). All records were smoothed with a 7-point running mean to remove highfrequency variations $\leq 6$ months and thus reduce noise in the monthly data, providing a better indication of possible climate behavior (Trenberth and Hoar, 1996).

\section{RESULTS AND DISGUSSION}

\section{Variance decomposition}

The EOF results show that three main modes of variability are identified by the EOF decomposition, representing in total $78 \%$ of the variance of the ice-core, sea-ice and surface meteorological time series. EOF 1 explains $32 \%$ of the total
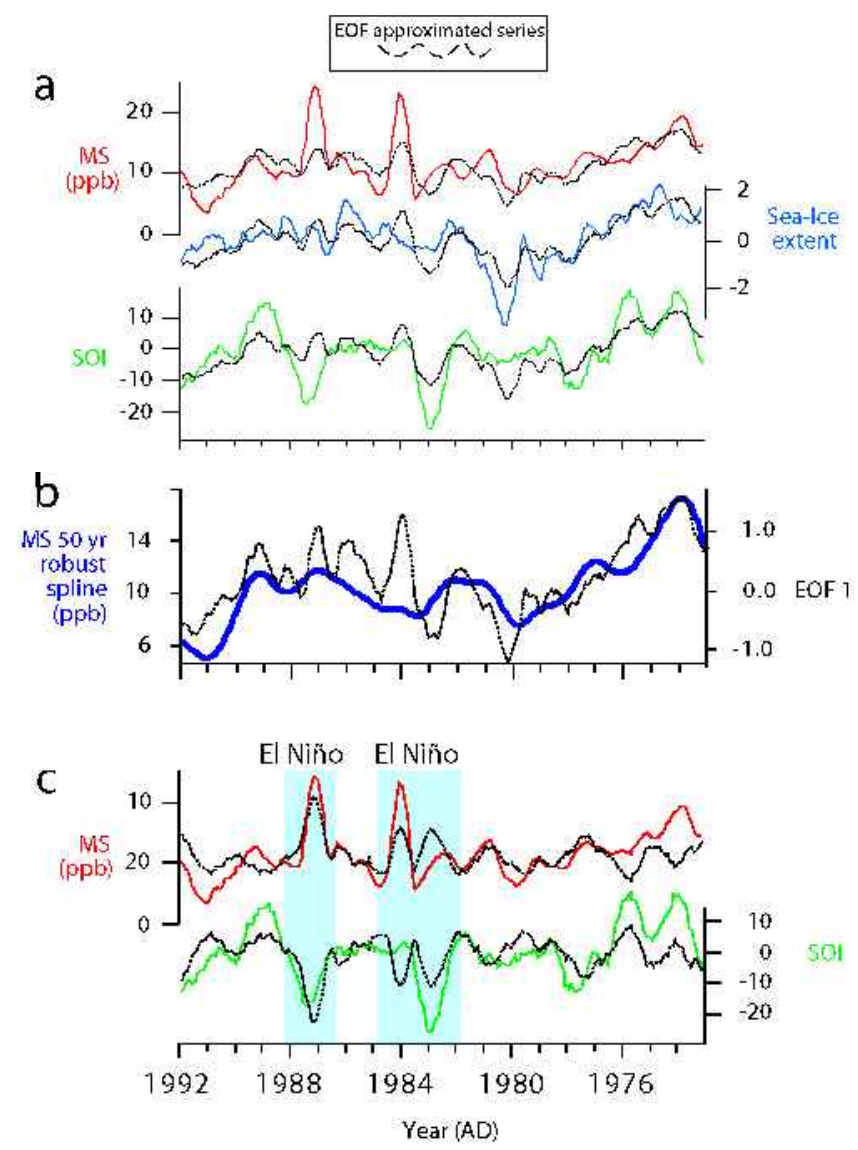

Fig. 4. Calibration of MS to instrumental series using EOF variance decomposition analysis, 1973-92. (a) EOF 1 approximated series (dashed curves) shown with $M S$ ( $p p b), A R$ seaice extent anomalies (developed from Jacka, 1983; and updates) and the standardized SOI. (b) 50 year smoothed MS robust spline calibrated $\left(r^{2}=0.55 ; p<0.01\right)$ to EOF 1 standardized approximation for sea-ice extent. (c) EOF 3 approximated series (dashed curves) shown with MS and the SOI.

variance in all the series and represents a positive relationship between $47 \%$ of MS, $65 \%$ of sea-ice extent and $47 \%$ of the SOI (Fig. 4). EOF 2 (30\% overall variance) represents $73 \%$ of the SPS surface pressure anomalies and $72 \%$ of the temperature anomalies. EOF 3 explains $16 \%$ of the overall total variance and reveals an inverse relationship between MS and the SOI at $37 \%$ and $38 \%$ explained variance, respectively (Fig. 4).

The highest overall variance among the explored records is represented by EOF 1 which displays a positive relationship between SP95 MS concentrations, AR region sea-ice extent and the SOI (Fig. 4). Studies of ice-core MS records from two Antarctic coastal sites, Newall Glacier and Law Dome (Welch and others, 1993; Phillips, 1998) (Fig. 3), also reveal a positive relationship between sea-ice latitudinal extent and increased MS. EOF 2 associates $75 \%$ of the variance in both the SPS surface pressure and temperature series. Previous studies linking the SOI to South Pole meteorological data identify lagged responses in surface temperature (Savage and others, 1988; Smith and Stearns, 1993) and pressure (Smith and Stearns, 1993), which are not taken into account with EOF decomposition analysis. EOF 3 reveals an inverse relationship between MS and the SOI (Fig. 4). This association (i.e. increased MS and negative values of the SOI) supports statistically the association between the extreme MS events in the SP84 ice-core record (Legrand and 
Feniet-Saigne, 1991) and El Niño events (Quinn and Neal, 1992). The most notable structures of EOF 3 are the extreme events found in both the SP95 MS and the SOI, which correspond to the El Niño events in 1982-83 and 1987.

The separate and distinct MS signals in the SP95 core identified by EOF 1 and EOF 3 in the variance decomposition demonstrate that the SP95 glaciochemical MS is influenced by air masses that travel over sea-ice-related sources of dimethylsulfide (DMS) (EOF 1). During El Niño events (EOF 3), as suggested by Legrand and Feniet-Saigne (1991), the DMS in the high latitudes is either enhanced by productivity or more efficiently transported to South Pole.

We suggest, based on the EOF results, that all sources of MS reaching South Pole are in the high-latitude oceans surrounding Antarctica. An earlier hypothesis, based on the latitudinal distribution of $\mathrm{MS}$ and $\mathrm{nsSOO}_{4}{ }^{2-}$, submits that the majority of MS deposited at South Pole during non-El Niño years was from more temperate latitudes (Legrand and Feniet-Saigne, 1991; Legrand and others, 1992). Further investigation of $\mathrm{MS}$ and $\mathrm{nsSOO}_{4}{ }^{2-}$ has revealed that the prime latitudinal source band for Antarctic sulfur is from DMS that is south of 50-60 $\mathrm{S}$ (Legrand and Pasteur, 1998; Minikin and others, 1998). A more recent study, however, shows evidence that inferring the latitudinal origin of DMS with the ratios of $\mathrm{MS}$ to $\mathrm{nssSO}_{4}{ }^{2-}$ might be misleading because high-latitude ratio values are also seen at higher altitudes in the low latitudes (Dibb and others, 1999).

\section{Methanesulfonate-sea-ice reconstruction}

The dominant mode of MS deposition to South Pole, as represented by the first EOF loading series, is from sea-ice sources in the AR sector (Fig. 3). Sea-ice-associated MS at South Pole is also positively correlated with the SOI in EOF 1 . This relationship suggests that this MS is incorporated with air masses that travel over the $\mathrm{AR}$ sea-ice sector $\left(185-245^{\circ} \mathrm{E}\right)$ and is eventually precipitated out in the West Antarctic sector, where it is most likely incorporated into snow at South Pole. There is additional MS deposition to South Pole (EOF 3) during El Niño events from a source that is statistically unrelated to sea ice in the AR sector, notably the open ocean and/or another sea-ice source. Analysis of airflow into Antarctica shows that relatively warm air appears to enter the southern part of the polar plateau through a topographic low between the summit of the Transantarctic Mountains and the polar plateau (Hogan, 1997) (Fig. 3). Furthermore, marine aerosols circulating around lows in the Bellingshausen-Amundsen-Ross Seas area frequently reach the surface of the polar plateau as a consequence of this topographic low. An eastward shift in the ASL during El Niño events (Cullather and others, 1996) would increase the atmospheric content of MS in the southeastern Pacific sector $\left(\sim 270^{\circ} \mathrm{E}\right)$. We assume that upslope transport of this MS-laden air mass in the southerly direction through the topographic low (Hogan, 1997) contributes to the MS concentrations at South Pole. Therefore, the SP95 glaciochemical MS time series (1487-1992) not only provides an estimate of sea-ice extent in the AR region, but also provides a marker for $\mathrm{El}$ Niño-associated changes in high-latitude circulation.

EOF 1 provides an estimate for background values in the SP95 MS, AR sea-ice extent and the SOI over the time period 1973-92 and demonstrates a direct relationship with sea-ice extent in the AR region (Fig. 4). Before this relationship is extended over the 500 year record of SP95 MS, the possible loss of MS in the upper portion of the core contri- buting to the downward trend from the present to 1940 is addressed. The two time periods separated by the break, 1487-1940 and 1940-92, were standardized separately by subtracting out their relative means, and then dividing by their respective standard deviations. Justification for treating the MS series as two distributions (1487-1940, 1940-92) stems from the $t$-test results that demonstrate that these two periods have significantly different means.

A strong correlation $\left(r^{2}=0.55 ; \mathrm{p}<0.01\right)$ between EOF 1 (MS-sea-ice loading series) and a $\sim 50$ year smoothed MS robust-spline curve demonstrates that the robust spline approximates the EOF calibration signal (Fig. 4). The $\sim 500$ year SP95 MS proxy for sea-ice extent in the AR sector is dominated by multi-decadal variability with a distinct shift at $\sim$ AD 1800 from higher-frequency variations (1550-1800) to lower-frequency variations (1800-1940) (Fig. 2). The MS proxy for sea ice also reveals periods of increased sea-ice extent relative to the present $(1800-50,1900-40)$ as well as periods of decreased sea-ice extent relative to the present (1550-1610, 1660-1710, 1760-1800). There is also relatively increased sea-ice extent from $\sim \mathrm{AD} 1800$ to 1940 as compared to 1550-1800. Longer records of Antarctic sea-ice extent have been ascertained from whaling records (de la Mare, 1997), but the number of observations in the Amundsen and Ross Seas results in low temporal resolution and therefore precludes accurate comparison.

\section{Methanesulfonate-El Niño reconstruction}

Legrand and Feniet-Saigne (1991) demonstrated in their seminal work that increases in South Pole MS were associated with El Niño events in the historical chronology (Quinn and others, 1987). A separate study (Isaksson, 1994) confirmed this finding by using an MS record from Dronning Maud Land, on the polar plateau, covering the period 1865-1992. Our exploratory EOF analysis also identifies, and significantly expands the findings of, an inverse relationship between SP95 MS and the SOI that statistically supports these previous findings. Visual inspection of the SP95 MS record shows that there is a strong association between elevated MS and El Niño events in the historical record (Quinn and Neal, 1992) within the dating error of the ice core (Fig. 2).

To extract an El Niño chronology from the SP95 MS record, the series was first detrended by subtracting out the $\sim 50$ year smoothed MS robust spline that represents the seaice-associated MS described earlier. The time periods (194092, 1487-1940) were then standardized as described earlier, to account for MS loss. SP95 standardized MS residuals $\geq 1$ standard deviation $(\sigma)$ were selected as El Niño-related MS peaks (Fig. 2) and were then correlated at \pm 2 years to the historical record of El Niño events (Quinn and Neal, 1992). We used a truncation level of $1 \sigma$ to objectively ensure that only the elevated levels of MS, comparable to those identified by Legrand and Feniet-Saigne (1991) are considered (16\% of the MS values). We compared the standardized MS residual peaks $\geq 1 \sigma$ to the historical record of El Niño events (Quinn and Neal, 1992) to test the validity of SP95 as a proxy for El Niño. The MS peaks $\geq 1 \sigma$ that correlate to El Niño events for 1922-84 and 1860-1992 validate previous studies on polar plateau MS-El Niño relationships (Legrand and FenietSaigne, 1991; Isaksson, 1994).

The results of this correlation are displayed by century at the bottom of Figure 2. The results show that the MS proxy captures $88 \%$ of the $\mathrm{M}+$ and higher El Niño events 
in the Quinn and Neal (1992) record for the 1900-92 period. The capture results of the MS proxy decline to $68 \%$ for $1800-99$ and to $<50 \%$ for the time period $1600-1800$. The capture results for the earliest portion of the MS proxy, 1525-99, increase to $67 \%$. While the SP95 MS-El Niño proxy does not have a one-to-one reconstruction of the historical chronology of El Niño events (Quinn and Neal, 1992), it does provide an estimate of the polar expression of El Niño back to 500 years BP. As such, the SP95 record is valuable in the reconstruction of global teleconnection patterns of climate change associated with the El NiñoSouthern Oscillation (ENSO) system.

\section{GONGLUSIONS}

From the SP95 MS-El Niño proxy we suggest that either the capture efficiency of high-level MS decreased from 1600 to 1800 or the El Niño impact on the polar latitudes declined during this period. We do not believe that the explanation relates to capture efficiency since the capture efficiency in the earliest portion of the record, the 16th century, is comparable to that in the 19 th century. We therefore assume that the lower correlation between the SP95 MS-El Niño proxy and the historical record from 1600-1800 demonstrates that there could be a decoupling between the tropical ENSO system and high-latitude circulation at a time when variations in the MS-sea-ice proxy are relatively more variable (1550-1800). Decoupling between the ENSO system and the high latitudes indicates large-scale changes in Southern Hemisphere climate during this period relative to the remainder of the record. It is notable that this decoupling occurs not only during periods when sea-ice extent is less but also when sea-ice variability is high. An example of this decoupling at a finer scale (monthly) is the regime shift in correlation from positive to negative seen at $\sim 1990$ between the SOI and West Antarctic precipitation (Cullather and others, 1996; Bromwich and others, 2000).

Frequency analysis on the historical El Niño chronologies from South America (Quinn and Neal, 1992) and the Nile region (Quinn, 1992) reveals significant changes as a function of temperature, notably increased El Niño activity during the period of the Little Ice Age (LIA; nominally 1400-1900) (Anderson, 1992) and decreased El Niño activity during the Medieval Warm Period (nominally 9501250) (Anderson, 1992; de Putter and others, 1998). The SP95 MS-sea-ice proxy is indicative of regional temperatures within the LIA period in the southeastern Pacific seaice sector for the last 500 years. The shift at $\sim 1800$ towards generally cooler conditions (increased sea-ice extent) in this region is concurrent with an increase in the frequency of $\mathrm{El}$ Niño events in the SP95 MS-El Niño proxy, as well as an increase in the frequency of events in the independent historical El Niño record (Quinn and Neal, 1992) (Fig. 2). This multi-decadal to centennial-scale relationship in the SP95 record between cooler (warmer) conditions and increased (decreased) occurrence of El Niño events supports the previous study (Anderson, 1992). The short-term trend in the instrumental SOI since 1970 towards more El Niño events (Trenberth and Hoar, 1997) is associated with a rise in average global temperatures. This departure in the longer-term El Niño-temperature relationship may suggest a different mode of operation at present, or that ENSO-temperature associations can vary on annual to decadal and centennial scales.

\section{ACKNOWLEDGEMENTS}

We thank: M. Battle, M. Bender, T. Sowers, D. Giles and J. Kyne for collecting the SP95 core during their fieldwork supported by the U.S. National Science Foundation; C. M. Zdanowicz and R. Boudrow for technical assistance; the Climate Change Research Center ion chromatography laboratory staff; J. Horsman for freezer assistance; J. Dibb, K. Hibbard, B. Keim, D. Z. Smith and C. Wake for reviewing the manuscript; S. Palmer for graphical support; and the two anonymous referees for their thorough reviews and detailed comments that helped to improve our manuscript.

\section{REFERENGES}

Anderson, R.Y. 1992. Long-term changes in the frequency of occurrence of El Niño event. In Diaz, H. F. and V. Markgraf, eds. El Niño. Historical and paleoclimatic aspects of the Southern Oscillation. Cambridge, Cambridge University Press, 193-200.

Bromwich, D. H., A. N. Rogers, P. Kållberg, R. I. Cullather, J.W. C. White and K. J. Kreutz. 2000. ECMWF analyses and reanalyses depiction of ENSO signal in Antarctic precipitation. f. Climate, 13(8), 1406-1420.

Buck, C. F., P. A. Mayewski, M. J. Spencer, S. Whitlow, M. S. Twickler and D. Barrett. 1992. Determination of major ions in snow and ice cores by ion chromatography. 7. Chromatogr., 594(1-2), 225-228.

Bunt, J. S. and E. F. J. Wood. 1963. Microalgae and Antarctic sea ice. Nature, $199(4900), 1254-1255$.

Carleton, A. M. 1989. Antarctic sea-ice relationships with indices of the atmospheric circulation of the Southern Hemisphere. Climate Dyn., 3(4), 207-220.

Charlson, R. J., J. E. Lovelock, M. O. Andreae and S. G. Warren. 1987. Oceanic phytoplankton, atmospheric sulphur, cloud albedo and climate. Nature, 326(6114), 655-66l.

Clarke, D. B. and S. F. Ackley. 1984. Sea ice structure and biological activity in the Antarctic marginal ice zone. F. Geophys. Res., 89(C2), 2087-2095.

Cole, J. E., R. G. Fairbanks and G. T. Shen. 1993. Recent variability in the Southern Oscillation: isotopic results from a Tarawa Atoll coral. Science, 260(5115), 1790-1793

Cullather, R. I., D. H. Bromwich and M. L. Van Woert. 1996. Interannual variations in Antarctic precipitation related to El-Niño-Southern Oscillation. 7. Geophys. Res., 101(D14), 19,109-19,118.

De la Mare, W. K. 1997. Abrupt mid-twentieth century decline in Antarctic sea-ice extent from whaling records. Nature, 389(6646), 57-61.

De Putter, T., M.-F. Loutre and G. Wansard. 1998. Decadal periodicities of Nile River historical discharge (A.D. 622-1470) and climatic implications. Geophys. Res. Lett., 25(16), 3195-3197.

Diaz, H. F. and G. N. Kiladis. 1992. Atmospheric teleconnections associated with the extreme phase of the Southern Oscillation. In Diaz, H. F. and V. Markgraf, eds. El Niño. Historical and paleoclimatic aspects of the Southern Oscillation. Cambridge, Cambridge University Press, 7-22.

Diaz, H. F. and V. Markgraf. 1992. Introduction. In Diaz, H. F. and V. Markgraf, eds. El Niño. Historical and paleoclimatic aspects of the Southern Oscillation. Cambridge, Cambridge University Press, 1-4.

Dibb, J. E. and 7 others. 1999. Aerosol chemical composition and distribution during the Pacific Exploratory Mission (PEM) Tropics. F. Geophys. Res., 104(D5), 5785-5800.

Glantz, M. H. 1991. Introduction. In Glantz, M. H., R.W. Katz and N. Nicholls, eds. Teleconnections linking worldwide climate anomalies. Cambridge, Cambridge University Press, 1-12.

Gloersen, P. 1995. Modulation of hemispheric sea-ice cover by ENSO events. Nature, 373(6514), 503-506.

Hansen, J. and S. Lebedeff. 1988. Global surface air temperature: update through 1987. Geophys. Res. Lett., 15(4), 323-326.

Hogan, A. 1997. A synthesis of warm air advection to the South Polar Plateau. 7. Geophys. Res., 102(D12), 14,009-14,020.

Isaksson, E. 1994. El Niño events and tropical sea surface temperatures recorded in an Antarctic snow core. In Climate records from shallow firn cores, Dronning Maud Land, Antarctica. Stockholm, Stockholm University. Department of Physical Geography; Edsbruk, Akademitryck AB, Paper V. (Avhandling/Dissertation 2.)

Jacka, T. H. 1983. A computer data base for Antarctic sea ice extent. ANARE Res. Notes 13

Jacka, T. H., L. Christou and B. J. Cook. 1984. A data bank of mean monthly and annual surface temperatures for Antarctica, the Southern Ocean and South Pacific Ocean. ANARE Res. Notes 22.

Jouzel, J., L. Merlivat, J. R. Petit and C. Lorius. 1983. Climatic information 
over the last century deduced from a detailed isotopic record in the South Pole snow. F. Geophys. Res., 88(C4), 2693-2703.

Kreutz, K. J., P. A. Mayewski, S. I. Whitlow and M. S. Twickler. 1998. Limited migration of soluble ionic species in a Siple Dome, Antarctica, ice core. Ann. Glaciol., 27, 371-377.

Ledley, T. S. and Z. Huang. 1997. A possible ENSO signal in the Ross Sea. Geophys. Res. Lett., 24(24), 3253-3256.

Legrand, M. and C. Feniet-Saigne. 1991. Methanesulfonic acid in south polar snow layers: a record of strong El Niño? Geophys. Res. Lett., 18(2), 187-190.

Legrand, M. and E. C. Pasteur. 1998. Methane sulfonic acid to non-sea-salt sulfate ratio in coastal Antarctic aerosol and surface snow. f. Geophys. Res., 103(D9), 10,991-11,006.

Legrand, M., C. Feniet-Saigne, E. S. Saltzman and C. Germain. 1992. Spatial and temporal variations of methanesulfonic acid and non sea salt sulfate in Antarctic ice. 7. Atmos. Chem., 14(1-4), 245-260.

Meyerson, E. A. 1999. Amundsen-Ross Sea ice variability and the extratropical expression of ENSO as recorded in a South Pole glaciochemical series. (M.Sc. thesis, University of New Hampshire.)

Minikin, A. and 7 others. 1998. Sulfur-containing species (sulfate and methanesulfonate) in coastal Antarctic aerosol and precipitation. 7. Geophys. Res., 103(D9), 10,975-10,990.

Mulvaney, R., E. C. Pasteur, D. A. Peel, E. S. Saltzman and P.-Y. Whung. 1992. The ratio of MSA to non-sea-salt sulphate in Antarctic Peninsula ice cores. Tellus, 44B (4), 295-303.

Nelson, D. M., W. O. Smith, Jr, L. I. Gordon and B. A. Huber. 1987. Spring distributions of density, nutrients, and phytoplankton biomass in the ice edge zone of the Weddell-Scotia Sea. 7. Geophys. Res., 92(C7), 7181-7190/7225.

Phillips, K. 1998. Sources of natural variability in an MSA ice core record from Law Dome, Antarctica. (Honours thesis, University of Tasmania. Institute of Antarctic and Southern Ocean Studies.)

Quinn, W. H. 1992. A study of Southern Oscillation-related climatic activity for A.D. 622-1990 incorporating Nile River flood data. In Diaz, H. F. and V. Markgraf, eds. El Niño. Historical and paleoclimatic aspects of the Southern Oscillation. Cambridge, Cambridge University Press, 119-149.
Quinn, W. H. and V. T. Neal. 1992. The historical record of El Niño events. In Bradley, R. S. and P. D. Jones, eds. Climate since A.D. 1500. London, etc., Routledge, 623-648.

Quinn, W. H., V. T. Neal and S. E. Antunez de Mayolo. 1987. El Niño occurrences over the past four and a half centuries. F. Geophys. Res., 92(C13), $14,449-14,461$.

Saigne, C. and M. Legrand. 1987. Measurements of methanesulphonic acid in Antarctic ice. Nature, 330(6145), 240-242

Savage, M. L., C. R. Stearns and G. A. Weidner. 1988. The Southern Oscillation in Antarctica. In 2nd Conference on Polar Meteorology and Oceanography, 29-31 March 1989, Madison, Wisconsin. Boston, MA, American Meteorological Society, 141-144. (Preprint.)

Simmonds, I. and T. H. Jacka. 1995. Relationships between the interannual variability of Antarctic sea ice and the Southern Oscillation. 7. Climate, 8(3), 637-647.

Smith, S. R. and C. R. Stearns. 1993. Antarctic pressure and temperature anomalies surrounding the minimum in the Southern Oscillation index. f. Geophys. Res., 98 (D7), 13,071-13,083.

Stahle, D. W. and 14 others. 1998. Experimental dendroclimatic reconstruction of the Southern Oscillation. Bull. Am. Meteorol. Soc., 79(10), 2137-2152.

Trenberth, K. E. and T. J. Hoar. 1996. The 1990-1995 El Niño-Southern Oscillation event: longest on record. Geophys. Res. Lett., 23(1), 57-60.

Trenberth, K. E. and T. J. Hoar. 1997. El Niño and climate change. Geophys. Res. Lett., 24(23), 3057-3060.

Wagnon, P., R. J. Delmas and M. Legrand. 1999. Loss of volatile acid species from upper firn layers at Vostok, Antarctica. 7. Geophys. Res., 104(D3), 3423-3431.

Welch, K. A., P. A. Mayewski and S. I. Whitlow. 1993. Methanesulfonic acid in coastal Antarctic snow related to sea ice extent. Geophys. Res. Lett., $20(6), 443-446$.

White, W. B. and R. G. Peterson. 1996. An Antarctic circumpolar wave in surface pressure, wind, temperature and sea-ice extent. Nature, 380(6576), 699-702. 